University of Montana

ScholarWorks at University of Montana

$11-2010$

\title{
Parental Investment Decisions in Response to Ambient Nest- Predation Risk Versus Actual Predation on the Prior Nest
}

Anna D. Chalfoun

Thomas E. Martin

University of Montana - Missoula, tom.martin@umontana.edu

Follow this and additional works at: https://scholarworks.umt.edu/wildbio_pubs

Part of the Life Sciences Commons

Let us know how access to this document benefits you.

\section{Recommended Citation}

Chalfoun, Anna D. and Martin, Thomas E., "Parental Investment Decisions in Response to Ambient NestPredation Risk Versus Actual Predation on the Prior Nest" (2010). Wildlife Biology Faculty Publications.

41.

https://scholarworks.umt.edu/wildbio_pubs/41

This Article is brought to you for free and open access by the Wildlife Biology at ScholarWorks at University of Montana. It has been accepted for inclusion in Wildlife Biology Faculty Publications by an authorized administrator of ScholarWorks at University of Montana. For more information, please contact scholarworks@mso.umt.edu. 


\title{
PARENTAL INVESTMENT DECISIONS IN RESPONSE TO AMBIENT NEST-PREDATION RISK VERSUS ACTUAL PREDATION ON THE PRIOR NEST
}

\author{
Anna D. Chalfoun ${ }^{1}$ and Thomas E. Martin \\ USGS Montana Cooperative Wildlife Research Unit, University of Montana, Missoula, MT 59812
}

\begin{abstract}
Theory predicts that parents should invest less in dependent offspring with lower reproductive value, such as those with a high risk of predation. Moreover, high predation risk can favor reduced parental activity when such activity attracts nest predators. Yet, the ability of parents to assess ambient nest-predation risk and respond adaptively remains unclear, especially where nest-predator assemblages are diverse and potentially difficult to assess. We tested whether variation in parental investment by a multi-brooded songbird (Brewer's Sparrow, Spizella breweri) in an environment (sagebrush steppe) with diverse predators was predicted by ambient nest-predation risk or direct experience with nest predation. Variation among eight sites in ambient nest-predation risk, assayed by daily probabilities of nest predation, was largely uncorrelated across four years. In this system risk may therefore be unpredictable, and aspects of parental investment (clutch size, egg mass, incubation rhythms, nestling-feeding rates) were not related to ambient risk. Moreover, investment at first nests that were successful did not differ from that at nests that were depredated, suggesting parents could not assess and respond to territorylevel nest-predation risk. However, parents whose nests were depredated reduced clutch sizes and activity at nests attempted later in the season by increasing the length of incubation shifts (on-bouts) and recesses (off-bouts) and decreasing trips to feed nestlings. In this unpredictable environment parent birds may therefore lack sufficient cues of ambient risk on which to base their investment decisions and instead rely on direct experience with nest predation to inform at least some of their decisions.
\end{abstract}

Key words: behavioral plasticity, Brewer's Sparrow, incubation, nest predation, nestling feeding rate, parental care, prior information, Spizella breweri.

\section{Decisiones de Inversión Parental en Respuesta al Riesgo Ambiental de Depredación de Nidos versus Depredación Concreta del Nido Anterior}

Resumen. La teoría predice que la inversión parental debería ser menor si la progenie tiene poco valor reproductivo, como cuando tiene un alto riesgo de depredación. Además, un alto riesgo de depredación puede reducir la actividad parental si esa actividad atrae depredadores. Sin embrago, la habilidad de los padres de determinar los niveles ambientales de riesgo de depredación y de responder de forma adaptativa permanece poco clara, especialmente cuando el ensamble de depredadores del nido es diverso y difícil de determinar. Evaluamos si la variación en la inversión parental por parte de una especie con nidadas múltiples (Spizella breweri) en un ambiente (estepa arbustiva) con un ensamble diverso de depredadores, puede ser predicha por el riesgo ambiental de depredación o por la experiencia concreta de depredación del nido. La variación en el riesgo ambiental de depredación entre ocho sitios, determinada por las probabilidades diarias de depredación del nido, no se correlacionó entre los cuatro años. En este sistema, el riesgo sería, por lo tanto, no predecible, y los aspectos de inversión parental (tamaño de la puesta, peso de los huevos, ritmo de incubación, tasa de alimentación de polluelos) no se relacionaron al riesgo ambiental. Además, la inversión en los primeros nidos no difirió con la inversión observada en nidos que fueron depredados, lo que sugiere que los padres no pudieron determinar ni responder a los niveles de riesgo de depredación a nivel de sus territorios. Sin embrago, las parejas cuyos nidos fueron depredados redujeron el tamaño de sus nidadas y su actividad en sus intentos de anidación posteriores, al aumentar el tiempo en que permanecieron en y fuera del nido durante la incubación y al disminuir sus tasas de visitación al nido para alimentar a sus polluelos. En este ambiente no predecible, las parejas de aves pueden tener una falta de señales sobre el riesgo ambiental en los cuales basar sus inversiones y, en vez de eso, dependen de la experiencia concreta de depredación de sus nidos para tomar por lo menos algunas de sus decisiones.

Manuscript received 9 December 2009; accepted 1 June 2010.

${ }^{1}$ Current address: USGS Wyoming Cooperative Fish and Wildlife Research Unit, Department of Zoology \& Physiology, University of Wyoming, Laramie, WY 82071. E-mail: achalfou@uwyo.edu

The Condor, Vol. 112, Number 4, pages 701-710. ISSN 0010-5422, electronic ISSN 1938-5422. (C 2010 by The Cooper Ornithological Society. All rights reserved. Please direct all requests for permission to photocopy or reproduce article content through the University of California Press's Rights and Permissions website, http://www.ucpressjournals.com/ reprintInfo.asp. DOI: 10.1525/cond.2010.090242 


\section{INTRODUCTION}

Investment in current offspring is critical to fitness yet also can be costly to investment in future offspring, so that parents must allocate resources to current reproduction appropriately in order to maximize their lifetime reproductive success (Williams 1966, Martin 1987, Roff 1992). Life-history theory predicts that individuals should decrease investment in current offspring whose probability of survival, and thus reproductive value, is low (Haig 1990, Wisenden 1993, Ghalambor and Martin 2000, Gunness et al. 2001, Rytkönen 2002). Increased risk of nest predation can reduce the reproductive value of an attempt at breeding and favor reduced parental investment, as through reduced egg size, clutch size, incubation effort, and parental feeding rates (Slagsvold 1982, Martin 1992, 1995, Wisenden 1993, Cresswell 1997, Kudo 2006, Martin and Briskie 2009). At the same time, high predation risk can favor reduced activity levels of parents at or near nests when such activity attracts enemies and so reinforce reduced investment at high-risk nests (Skutch 1949, Martin et al. 2000, Muchai and du Plessis 2005, Fontaine et al. 2007, Eggers et al. 2008, Massaro et al. 2008, Peluc et al. 2008). Yet, parental adjustments may also depend on local predator communities because the predictability of predation risk, availability of cues indicating risk, and the extent to which parental care attracts predators may vary (Martin 1992, Roper and Goldstein 1997, Ghalambor and Martin 2002).

The responses of parents in environments where predators are less predictable, however, have not been carefully studied (Martin and Briskie 2009). Previously, decisions about reproductive investment relative to the ambient risk of nest predation have been studied predominantly within systems with only a few obvious diurnal species of predator (e.g., squirrels, corvids, shrikes; Scheuerlein et al. 2001, Ghalambor and Martin 2000, 2002, Eggers et al. 2005, 2006, 2008, Fontaine and Martin 2006, Peluc et al. 2008). In such cases, experiments and observational data suggest that parents assess the risk of nest predation and decrease investment in high-risk environments. Behavioral and reproductive plasticity should be particularly favored in variable environments, but appropriate responses depend on the variation being predictable and assessable (Martin 1995, Ghalambor and Martin 2002, Wingfield 2003, Lima 2009, Martin and Briskie 2009). We ask here whether in environments where nest predators are more variable and potentially unpredictable, parents can assess and respond to ambient risk of nest predation. In some environments predation may be much less predictable because there are many species of predators with diverse activity periods (diurnal and nocturnal) and foraging strategies (visual, olfactory, heat-sensing). One habitat with a diverse community of predators with a suite of tactics of search for prey is sagebrush (Vander Haegen et al. 2002, Chalfoun and Martin 2007a, 2009, also see later). As expected with such a diverse predator community, we observed high variation in nest-predation risk both among eight study sites in sagebrush habitat and from year to year, though not in a correlated pattern (also see Rotenberry and Wiens 1989). We use this variation to examine whether birds can assess the risk of ambient nest predation and adjust their reproductive tactics accordingly.

If parent birds cannot predict the risk of nest predation accurately, an alternative strategy might be to adjust investment in future nesting attempts in direct response to predation on an initial attempt (e.g., see Marzluff 1988 for an example of nest position being shifted in response to predation on a prior attempt). If predation is spatially correlated, loss of an initial clutch may indicate that subsequent attempts run a higher risk of predation. In such cases, parents whose initial nest was depredated should (1) lower investment and care in the next attempt so that resources remain for multiple attempts (Slagsvold 1982, 1984, Martin 1992, 1995) and/or (2) limit activities that could increase predation risk (Martin and Briskie 2009).

In summary, we examined whether the parental-investment tactics of a multi-brooded songbird varied in response to ambient levels of nest-predation risk where nest predators are variable and diverse. We further examined whether individuals altered parental investment in subsequent attempts following the predation of a previous nest. We focused on metrics with key consequences for fitness (clutch size, egg mass, incubation rhythms, nestling-feeding rates) and that have been observed to vary in response to nest-predation risk (see review in Martin and Briskie 2009).

\section{METHODS}

\section{STUDY SYSTEM}

We studied the Brewer's Sparrow (Spizella breweri), a multibrooded passerine that builds an open-cup nest in shrubs of the sagebrush steppe of western North America. In Brewer's Sparrow care is biparental; both females and males incubate and feed nestlings and fledglings, suggesting that parental investment is particularly important for offspring survival. Nest predation is the primary cause of nest failure for sagebrush songbirds, and it varies both spatially and temporally (Rotenberry and Wiens 1989, Mahoney et al. 2006, Chalfoun and Martin 2007a, 2009). Sagebrush habitats are typically host to a diversity of potential nest predators, including mammals, birds, and reptiles (Vander Haegen et al. 2002, Chalfoun and Martin 2007a) both diurnal and nocturnal with diverse foraging strategies (visual, olfactory, heat-sensing). This diversity and variability (also see Fig. 1) provided the basis for our study of the ability of parents to assess and respond to ambient risk or prior experience.

Our study took place within Carbon County, south-central Montana, from May to August, 2002-2005 at eight 25- to 30-ha sites separated by $\geq 1 \mathrm{~km}$ (Chalfoun and Martin 2007a, 2009). We began with four sites in 2002 and added four additional sites for 2003-2005. Sites were dominated by big sagebrush 


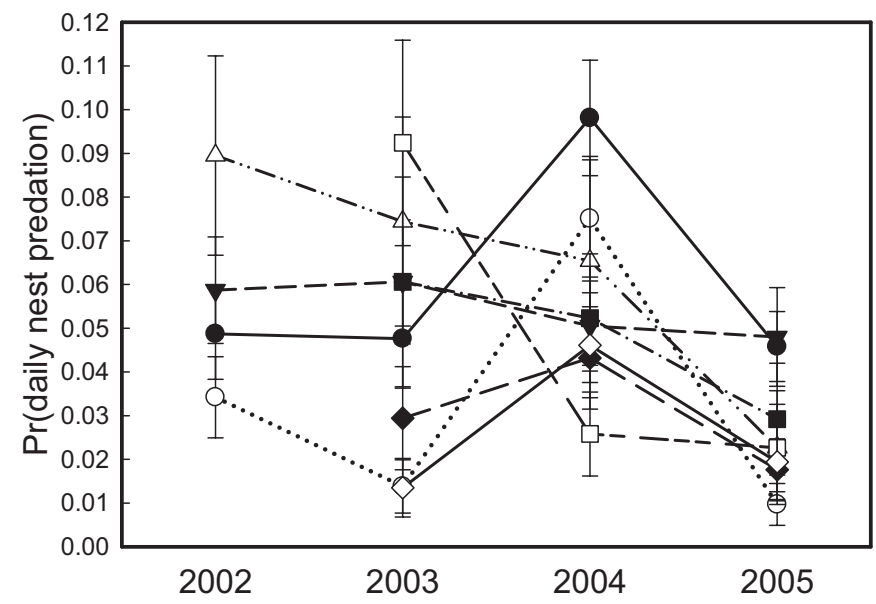

FIGURE 1. Daily probabilities ( $\pm 1 \mathrm{SE})$ of predation of Brewer's Sparrow nests $(n=762)$ across eight Montana sites (labeled with unique symbols) and four years of study demonstrating temporal and spatial variation in nest-predation risk. Each point represents the mean probability of nest predation within a site and year, and $n=$ $17-70$ nests per site per year.

(Artemisia tridentata) and had scattered greasewood (Sarcobatus vermiculatus) and rabbitbrush (Chrysothamnus spp.). Confirmed nest predators (via visual observation, video evidence, or fecal material in depredated nests) included the bullsnake (Pituophis melanoleucus), prairie rattlesnake (Crotalus viridis), least chipmunk (Tamias minimus), mice (Peromyscus spp.), and Loggerhead Shrike (Lanius ludovicianus). Other species present at the sites that have been observed depredating nests in other studies included the American Crow (Corvus brachyrhynchos), Common Raven (C. corax), Black-billed Magpie (Pica hudsonia), Pinyon Jay (Gymnorhinus cyanocephalus), Common Grackle (Quiscalus quiscula), Brown-headed Cowbird (Molothrus ater), voles (Microtus spp.), weasels (Mustela spp.), red fox (Vulpes vulpes), coyote (Canis latrans), and raccoon (Procyon lotor) (Sealy 1994, Sargeant et al. 1998, Pietz and Granfors 2000, Pärt and Wretenberg 2002, Vander Haegen et al. 2002, Thompson and Burhans 2003).

\section{NEST SEARCHING AND MONITORING}

We located nests via behavioral observations of parents and systematic nest searches of known territories, which are relatively small (0.5-1.0 ha; Wiens et al. 1986, Chalfoun and Martin 2007). To document if and how investment and behaviors of individual parents changed following nest predation, we color-banded and intensively monitored a subset of five to ten pairs of Brewer's Sparrows at each site each year. We target-netted focal birds at their first nests of the season and attempted to locate all their subsequent nests that season. Brewer's Sparrows are socially monogamous during a single nest attempt but occasionally divorce for subsequent nest attempts (Chalfoun, unpubl. data). Moreover, some pairs whose nests failed early abandoned their territories. Consequently, in our analyses of responses, we incorporated data only for banded pairs that we were able to monitor during at least two sequential nest attempts. We checked nests every 2 or 3 days (Martin and Geupel 1993) and considered them successful if they fledged at least one young and depredated if contents disappeared earlier than 2 days prior to the average time of fledging (Chalfoun and Martin 2007a). We used observations at and near the nest (i.e., fecal material on nest rims, parents feeding fledglings nearby) to confirm fledging if the nest was vacated late in the nestling period (Manolis et al. 2000); if we observed neither, we considered the nest depredated.

\section{EGG-STAGE METRICS}

We recorded the size of the clutch in all nests in which we observed a clutch on at least two successive visits between the end of laying and the end of incubation. During 2002, 2003, and 2005 we weighed the eggs in nests whose date of initiation (date first egg laid) we knew, if the eggs had been incubated for $<3$ days (to control for day of incubation and effects of evaporative water loss; Deeming 2002, Martin et al. 2006). Eggs were weighed on portable electronic balances sensitive to $0.001 \mathrm{~g}$ that were recalibrated each time they were relocated. At a subset of nests, we quantified nest attentiveness and mean bout lengths (times the birds were on and off the nest) via videotaping for 6-8 hours beginning within $0.5 \mathrm{hr}$ of sunrise (Martin 2002, Chalfoun and Martin 2007b). Video cameras were placed no closer than $3 \mathrm{~m}$ to nests and hidden from view with camouflaged material so that the parents were not disturbed by the presence of the camera, which could disrupt their normal behavioral rhythms. We filmed nests during mid-incubation (day 4-7) to control for potential effects of stage of incubation.

\section{NESTLING-STAGE METRICS}

We recorded nestling-feeding rates (trips per hour) by videotaping nests by methods similar to those for incubation. We restricted filming of nestlings to day 5, 6, or 7 of the 8-to 10 -day nestling period and to modal brood sizes of three or four to control for potential effects of age and brood size. During 2005, we quantified the sizes of food loads to test whether feeding trips were inversely related to the amount of food delivered. If food loads were sufficiently clear, we converted videos into .avi files with Adobe Premier. Following Martin et al. (2000), we then measured their size (in $\mathrm{mm}^{2}$ ) with the program Scion Imaging in reference to morphological features of known average size (such as the bill and tarsus) in the same image. We averaged the sizes of the food loads over the entire video record for each pair and used only data from videos containing at least two measurable food loads. 


\section{STATISTICAL ANALYSES}

Within each site during each year, we calculated daily probabilities of nest predation (Mayfield 1975) as a proxy for nestpredation risk at a population level. Nests that failed from other causes such as abandonment or extreme weather were rare $(0.4 \%)$ and right-censored in calculations so that we included exposure days prior to failure but restricted ultimate nest fates to success versus depredation. At each site, the number of nests suitable for Mayfield estimates ranged from 17 to 70 (median 29) per year. At our sites, estimates of daily nest predation were highly and negatively correlated with seasonal fecundity (total number of offspring fledged per pair per season; Chalfoun and Martin 2007a) so were suitable to represent nest-predation pressure at the population level. To test the consistency of nest-predation risk across sites and years we used one-tailed Pearson correlations of daily probabilities of nest predation among all sets of years. To simultaneously test the relative influence of year, site, and territory on the probability of nest predation we also ran a logistic exposure analysis (Shaffer 2004) of all subsequent nests of pairs for which we knew the fate of their first nest that season (i.e., successful or depredated). Using Akaike's information criterion adjusted for small sample size ( $\mathrm{AIC}_{c}$; Burnham and Anderson 2002), we then ranked eight models, including a constant-survival model and all possible combinations of year, site, and fate of first nest.

We also averaged, for each site and year, clutch size, egg mass, nest attentiveness, lengths of incubation on- and offbouts, and nestling-feeding rates. To examine parental responses in relation to nest-predation risk at the level of the site we used ANCOVA models with year as a random factor and site-level nest-predation probability and Julian date as covariates. The egg-mass model also included clutch size as a covariate, and the nestling-feeding-rate model also included brood size and nestling age as additional covariates. We did not obtain sufficient field data for all year-by-site combinations for all response variables.

To analyze the birds' responses to the previous nest's fate we first categorized subsequent attempts as post-predation or post-success on the basis of the outcome of the first attempt. Moreover, in order to test for the birds' potential assessment of ambient nest-predation risk at the territory scale and to account for potential variation due to variation in the parents' own quality, we further categorized first attempts as presuccess or pre-predation. We tested for differences in metrics of parental investment among the four categories of nest (1, first attempt, succeeded; 2, first attempt, depredated; 3, later attempt, following success of first attempt; 4, later attempt, following failure of first attempt) by using ANCOVA models with nest type as a fixed factor and Julian date as a covariate. Additional covariates for the various models included clutch size in the egg-mass model and brood size and stage day for the analysis of nestling feeding rate. We used post-hoc (least significant difference) tests to evaluate differences among the four nest types.

\section{RESULTS}

\section{VARIATION IN NEST PREDATION}

We derived daily probabilities of nest predation from a sample of 762 nests. Daily nest-predation rates varied from site to site within a year $(0.0135-0.0924)$ and from year to year within a site (0.0226-0.0924) (Fig. 1). Daily nest-predation rates across sites, though different between each year, were correlated in 2002 and 2003, when only four plots could be compared, and unrelated for all other pairs of years (Table 1). Year was included in all three of the top logistic exposure models evaluating the relative influence of year, site, and fate of previous nest on daily probability of survival of subsequent nests (Table 2). Site was in the third-best model, and all three of the top models were within $2 \Delta \mathrm{AIC}_{c}$ units of each other (Table 2). Probabilities of predation also varied considerably within a site, as indicated by error estimates shown in Fig. 1. Thus at the site level nest-predation risk was highly variable,

TABLE 1. Correlation matrix of daily probabilities of predation of Brewer's Sparrow nests across eight sites, by year. Data are one-tailed Pearson $r$ and $P$ values, with sample sizes of sites in parentheses.

\begin{tabular}{cccc}
\hline \hline & 2003 & 2004 & 2005 \\
\hline 2002 & $0.91(4)$ & $-0.38(4)$ & $0.09(4)$ \\
& $P=0.045$ & $P=0.33$ & $P=0.45$ \\
2003 & & $-0.30(8)$ & $0.37(8)$ \\
& & $P=0.24$ & $P=0.18$ \\
2004 & & & $0.30(8)$ \\
& & & $P=0.24$ \\
\hline
\end{tabular}

TABLE 2. Effects of year $(n=4)$, site $(n=8)$, and previous fate within a season (successful versus depredated) on daily probability of survival of subsequent nests of Brewer's Sparrows ( $n=245$ nests, 1762 observation intervals, and 3434 observation days). Number of model parameters $(K)$, the difference in $\mathrm{AIC}_{c}$ between the model and the best-fitting model $\left(\Delta \mathrm{AIC}_{c}\right)$, and Akaike weights $\left(w_{i}\right)$ are presented for eight logistic exposure models.

\begin{tabular}{lccc}
\hline \hline Model & $K$ & $\Delta \mathrm{AIC}_{c}$ & $w_{i}$ \\
\hline Year & 2 & $0.00^{\mathrm{a}}$ & 0.44 \\
Year, previous fate & 3 & 1.81 & 0.18 \\
Year, site & 3 & 2.00 & 0.16 \\
Constant survival & 1 & 3.49 & 0.08 \\
Year, site, previous fate & 4 & 3.81 & 0.07 \\
Previous fate & 2 & 5.02 & 0.04 \\
Site & 2 & 5.29 & 0.03 \\
Site, previous fate & 3 & 6.88 & 0.01 \\
\end{tabular}

${ }^{\mathrm{a}} \mathrm{AIC}_{c}=910.135$. 
both spatially and temporally, and inconsistent, suggesting it might be unpredictable.

In contrast to the inconsistent variation in nest-predation risk by site and year, territory-level risk was somewhat spatially correlated; pairs whose first nests were depredated had a greater chance of being depredated in subsequent attempts (Table 2). The fate of the previous nest was in the logistic exposure model with the second highest support when the relative influence of site-level and territory-level (fate of previous nest) factors on the probability of success of subsequent nests were considered simultaneously (Table 2). Therefore, nest predation was spatially auto-correlated at the territory level.

\section{RESPONSES TO AMBIENT RISK}

None of the parental-investment responses that we measured were significantly related to nest-predation probability at the site level (Table 3, Fig. 2). Clutch size varied annually, however, and declined through the season $\left(\beta=-0.012\right.$ eggs day $^{-1} \pm$ $0.001 \mathrm{SE})$. Egg mass increased marginally with Julian date ( $\beta=0.001 \mathrm{~g} \mathrm{day}^{-1} \pm 0.001$ ) independently of clutch size (Table 3 ). Incubation attentiveness ( $\%$ time on eggs) was consistent across years and within a season (Table 3 ). During incubation,

TABLE 3. Summary statistics for measures of parental care by Brewer's Sparrows in relation to site-level nest-predation risk, as assayed by estimates of the daily probability of nest predation. Data are from ANCOVA models with year as a random factor and time of season (Julian date) as a covariate.

\begin{tabular}{|c|c|c|c|}
\hline Metric & df & $F$ & $P$ \\
\hline \multicolumn{4}{|l|}{ Clutch size } \\
\hline Nest predation & 1,665 & 0.55 & 0.46 \\
\hline Year & 3,665 & 44.80 & $<0.001$ \\
\hline Julian date & 1,665 & 99.82 & $<0.001$ \\
\hline \multicolumn{4}{|l|}{ Egg mass } \\
\hline Nest predation & 1,126 & 1.64 & 0.20 \\
\hline Year & 2,126 & 0.70 & 0.50 \\
\hline Julian date & 1,126 & 3.56 & 0.06 \\
\hline Clutch size & 1,126 & 0.26 & 0.61 \\
\hline \multicolumn{4}{|c|}{ Length of incubation on-bouts } \\
\hline Nest predation & 1,91 & 0.03 & 0.88 \\
\hline Year & 3,91 & 3.61 & 0.02 \\
\hline Julian date & 1,91 & 0.09 & 0.77 \\
\hline \multicolumn{4}{|c|}{ Length of incubation off-bouts } \\
\hline Nest predation & 1,91 & 0.33 & 0.57 \\
\hline Year & 3,91 & 1.08 & 0.36 \\
\hline Julian date & 1,91 & 0.29 & 0.59 \\
\hline \multicolumn{4}{|c|}{ Nest attentiveness (\%) } \\
\hline Nest predation & 1,91 & 0.04 & 0.85 \\
\hline Year & 3,91 & 1.76 & 0.16 \\
\hline Julian date & 1,91 & 0.01 & 0.94 \\
\hline \multicolumn{4}{|c|}{ Feedings of nestlings $\mathrm{hr}^{-1}$} \\
\hline Nest predation & 1,126 & 0.34 & 0.56 \\
\hline Year & 3,126 & 3.27 & 0.02 \\
\hline Julian date & 1,126 & 6.13 & 0.02 \\
\hline Age of nestlings & 1,126 & 4.25 & 0.04 \\
\hline Brood size & 1,126 & 9.23 & 0.003 \\
\hline
\end{tabular}

the average length of an incubation shift (on-bout) varied annually but not seasonally, and the length of recesses from incubation (off-bouts) showed no response to any parameter (Table 3). Nestling-feeding rates varied annually, decreased seasonally $\left(\beta=-0.05\right.$ trips day $\left.{ }^{-1} \pm 0.02\right)$, and increased with nestling age $\left(\beta=+0.66\right.$ trips $^{-1} r^{-1}$ per 1-day increase in nestling age \pm 0.32$)$ and brood size $\left(\beta=1.36\right.$ trips hr $^{-1}$ per nestling \pm 0.45 ) (Table 3 ). Thus, while parental investment responses varied with year, Julian date, and attributes of the offspring, they did not vary with ambient risk of nest predation.

At the territory scale, parental investment at first nests that were successful did not differ significantly from that at first nests that were depredated for any of the parental metrics we investigated (LSD post-hoc tests; clutch size: $P=0.49$; egg mass: $P=0.23$; incubation attentiveness: $P=0.29$; length of incubation on-bouts: $P=0.17$; length of incubation off-bouts: $P=0.45$; incubation visits: $P=0.07$; nestling-feeding trips: $P$ $=0.69$; Figs. 3,4$)$. This lack of difference suggests that parents at nests of different fates did not differ in quality and they were not able to evaluate the risk of predation of the first nest they attempted.

\section{RESPONSES TO FATE OF THE PRIOR NEST}

The spatial auto-correlation of predation at the territory level (see above) may favor adjustment of parental care following predation of the prior nest. After depredation of their first nest, females significantly reduced the size of the clutch in replacement nests, even after a correction for Julian date (Table 4, Fig. 3). Egg mass was not explained by prior fate even after a slight increase with Julian date $\left(\beta=0.003 \mathrm{~g} \mathrm{day}^{-1} \pm\right.$ $0.002 \mathrm{SE}$ ) and variation in clutch size were accounted for (Table 4). Neither did incubation attentiveness vary with prior fate (Table 4, Fig. 3). The average duration of on-bouts, however, increased following failure of the previous nest (Table 4, Fig. 3). On-bouts were $9.9 \pm 4.04$ min longer, on average, following nest predation than during first attempts preceding predation. Off-bouts also tended to lengthen following previous nest failure (1.1 $\pm 1.7 \mathrm{~min}$; Fig. 3), though not significantly (LSD, $P=0.18$ ). The combined increase in length of on- and off-bouts yielded reduced parental activity at the nest during incubation $\left(\beta=-1.04 \pm 0.57\right.$ visits $\mathrm{hr}^{-1}$; Table 4, Fig. 3). After predation of the first nest, parents also decreased activity at the replacement nest by reducing the number of trips to feed nestlings, even after potential effects of brood size and nestlings' age were accounted for (Table 4, Fig. 4). On average, parents renesting following previous nest predation decreased feeding by 2.3 trips $\mathrm{hr}^{-1} \pm 1.4$ in comparsion to the rate at first nests before predation (Fig. 4). Food loads did not vary by previous fate $\left(F_{1,25}=0.48, P=\right.$ $0.62)$, brood size $\left(F_{1,25}=0.28, P=0.60\right)$, or the nestlings' age $\left(F_{1,25}=0.29, P=0.60\right)$ but, contrary to our prediction, were positively related to nestling-feeding rates (two-tailed Pearson $r=0.32, P=0.07)$. 


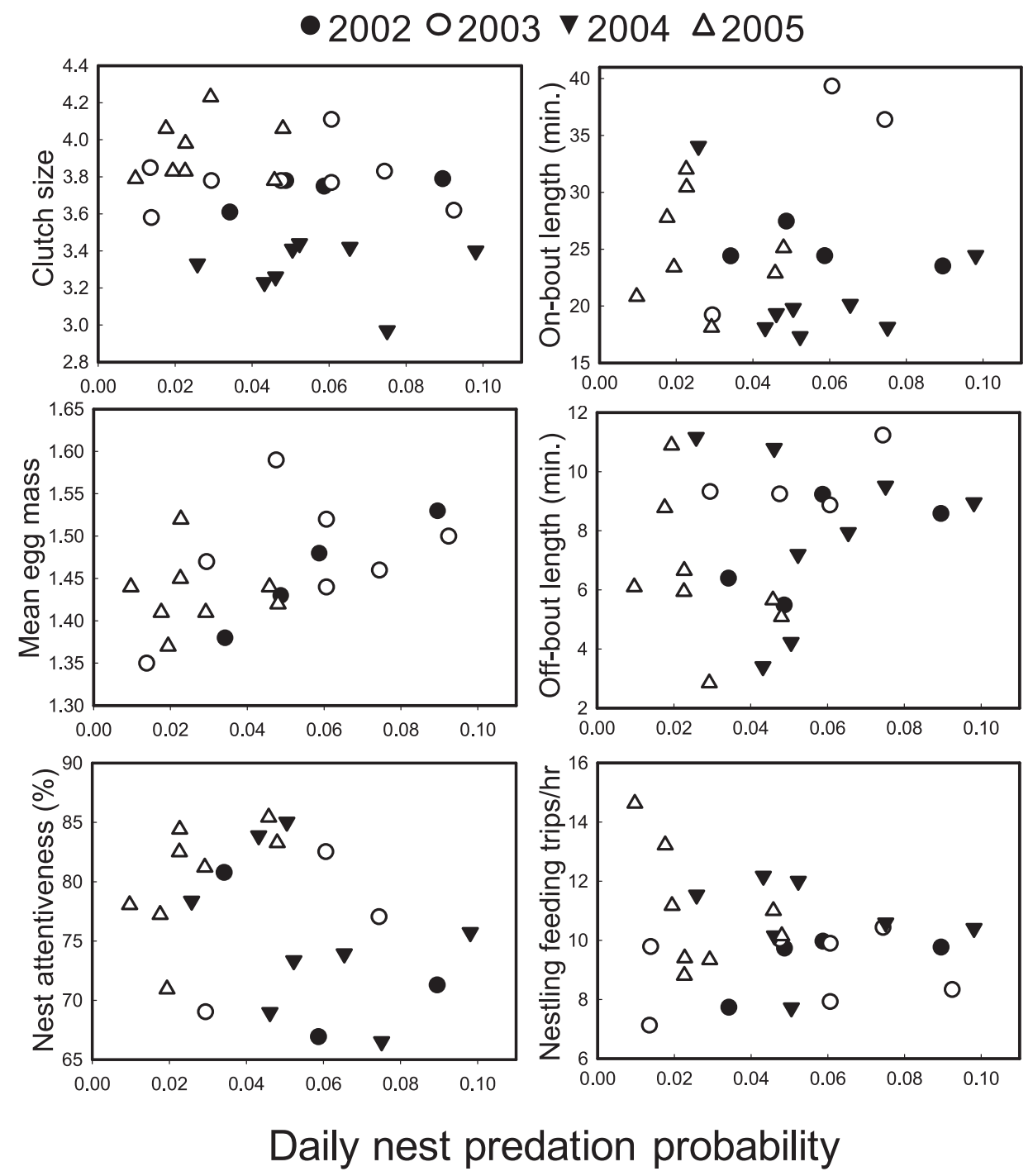

FIGURE 2. Measures of parental investment (clutch size, mean egg mass, incubation attentiveness, lengths of incubation shifts and recesses, and nestling-feeding rates) of Brewer's Sparrows in relation to ambient risk of nest predation (as assayed by daily probabilities of nest predation) at the population level. Points represent data from 762 nests, averaged by site and year.

\section{DISCUSSION}

Parental care is energetically costly, and theory predicts that parents should invest less in dependent offspring with a higher chance of mortality (Haig 1990, Wisenden 1993, Ghalambor and Martin 2000, 2002, Martin and Briskie 2009). Evidence suggests that breeding birds exposed to fairly simple assemblages of nest predator (e.g., one to a few readily observable diurnal species) can assess ambient nest-predation risk and adjust their strategies of parental care accordingly (Scheuerlein et al. 2001, Eggers et al. 2005, Fontaine and Martin 2006, Peluc et al. 2008). In unpredictable environments, however, the accurate assessment of the vulnerability of offspring may be hampered (Lima and Dill 1990, Lima and Bednekoff 1999, Ghalambor and Martin 2002). Brewer's Sparrows nesting where spatial and temporal variation in nest-predation risk was high (Tables 1, 2, Fig. 1) did not adjust their parental investment (as measured by clutch size, egg mass, incubation rhythms, nestling feeding rates) with variation in ambient risk of nest predation. These results suggest that in this complex environment with respect to nest predators (i.e., many nocturnal and diurnal species with diverse prey-search strategies), parents are largely unable to assess ambient nest-predation risk at the site level accurately, either because of the inconsistency of risk or lack of sufficient cues.

Nest-predation risk at the scale of the territory was more spatially predictable than that at the scale of the landscape; if a pair's first nest was depredated, the nests it attempted subsequently were more likely to be depredated (Table 2). As at 
First attempts
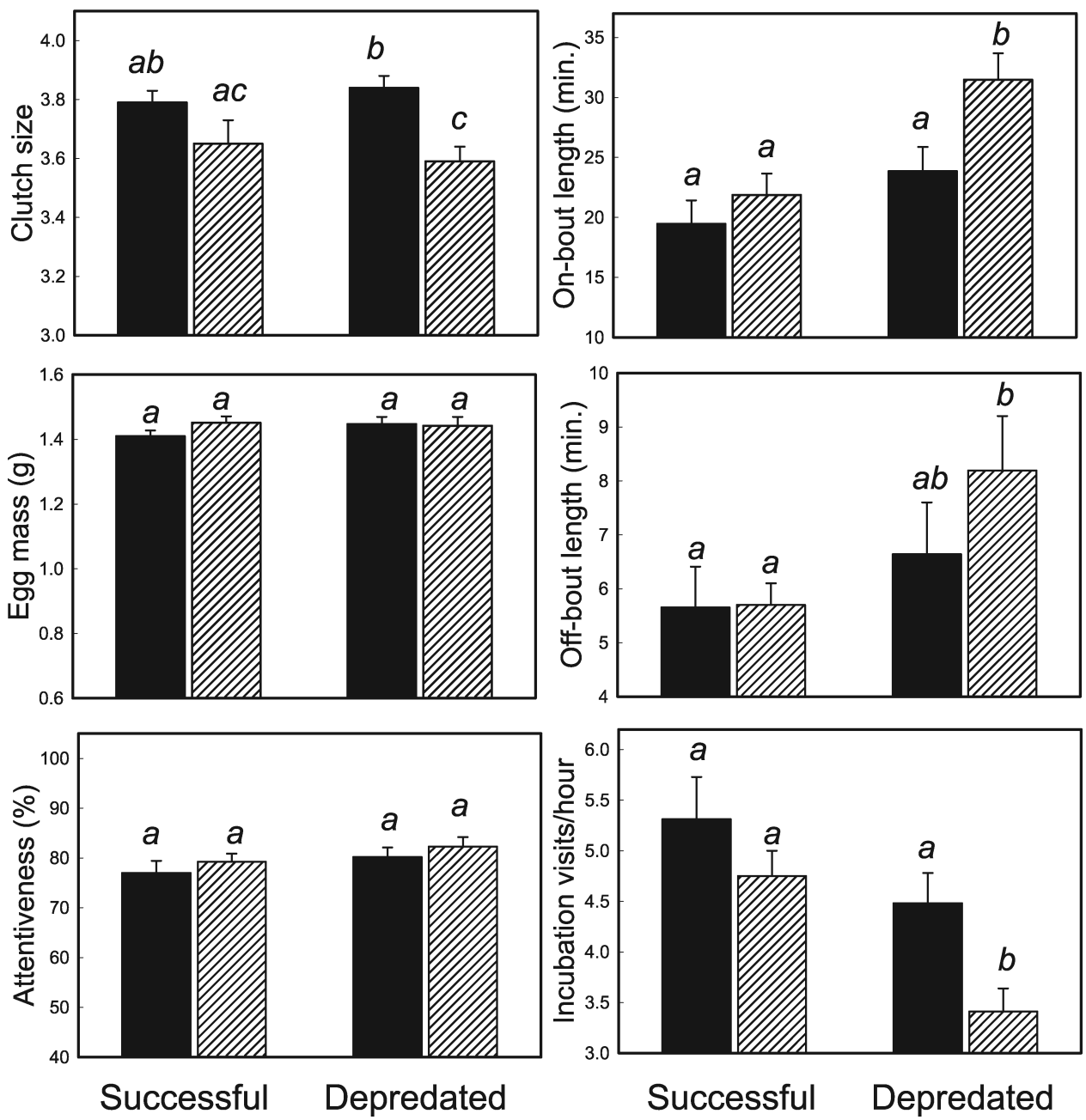

FIGURE 3. Clutch size ( $n=250$ nests; top left), egg mass ( $n=131$ nests; middle left), and incubation attentiveness ( $\%$ time on eggs; bottom left), length of incubation shifts (on-bout; top right), length of recesses from incubation (off-bout; middle right), and hourly nest visits [(60/(average duration of on- + off-bouts $) \times 2)$; bottom-right $](n=86$ nests $)$, for first and subsequent nests of Brewer's Sparrow in relation to fate (successful or depredated) of first nests. Bars represent means $\pm 1 \mathrm{SE}$, and variables with different letters were significantly different at $P=0.05$ by post-hoc LSD tests.

the site scale, however, assessment of nest-predation probability within a territory for a first attempt was likely unrealistic because the sizes of the home ranges or territories of the vast majority of potential nest predators at our study sites are much larger than that of Brewer's Sparrow territories (see Methods). Further substantiating this suggestion is the observation that investment by pairs whose first attempt was successful did not differ significantly from that of pairs whose first attempted nest was depredated, by any of the metrics we tested (Figs. $3,4)$. The correlation of nest-predation risk within a territory within a year, however, makes adjustments of attempts in the same season following nest predation a potentially adaptive response. Selection for adjustments in strategies for parental care should be favored within environments with variable but predictable predation risk (Martin 1995, Lima and Bednekoff 1999, Stoks et al. 1999, Wingfield 2003, Remeš 2005, Lima 2009). Indeed, pairs of Brewer's Sparrows whose previous nest attempts were depredated reduced the size of their next clutch and decreased activity at their next nest, a response long thought to reduce the proximate risk of nest predation (Skutch 1949, Conway and Martin 2000, Martin et al. 2000, Eggers et al. 2005, 2006, Fontaine and Martin 2006, Massaro et al. 2008, Peluc et al. 2008). The birds reduced their activity both by increasing the lengths of on- and off-bouts during incubation and decreasing trips to feed nestlings. Within this variable environment parents may therefore rely on prior experience to assess risk to offspring in subsequent nests and adjust their investment tactics accordingly. 


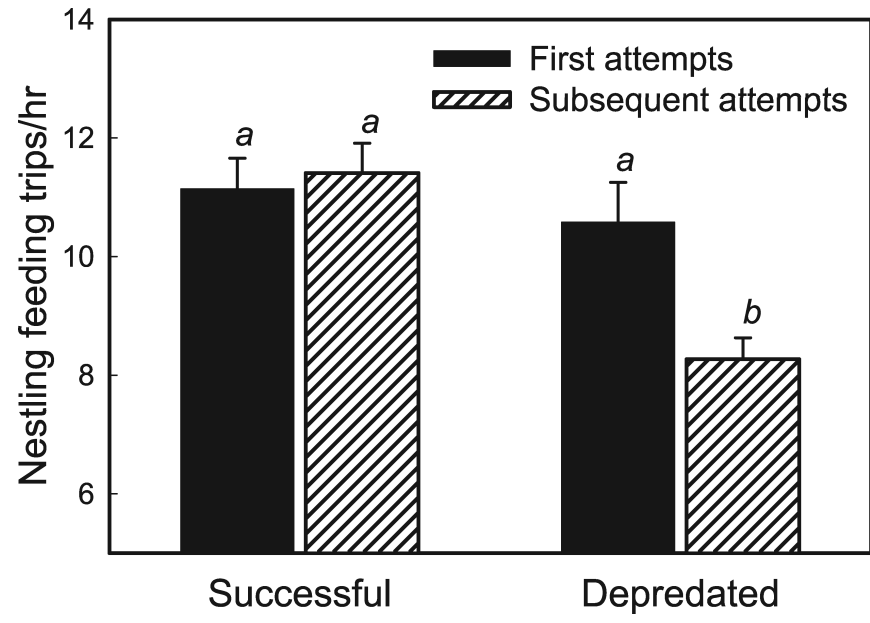

FIGURE 4. Mean ( $\pm 1 \mathrm{SE})$ rates at which nestling Brewer's Sparrows were fed in first nest attempts $(n=54)$ and in subsequent nests $(n=53)$ in relation to fate (successful or depredated) of first nests. The variables represented by bars with different letters were significantly different at $P=0.05$ by post-hoc LSD tests.

One possible alternative explanation for greater reductions in clutch size and parental activity in replacement nests following predation than in second nests following successful first nests is that the quality of pairs whose nests were depredated was lower. To test this alternative, ideally we would have compared metrics of parental investment of individual pairs through multiple nesting attempts within a season. Unfortunately, our sample sizes for duplicate measurements of pairs were too low. Still, comparisons of parental traits at successful first nests with those at depredated first nests provide some inference into possible differences in parental quality. The data suggest that such differences were not strong, given that clutch size, egg mass, nest attentiveness, and nestlingfeeding rates at successful and depredated first nests did not differ (Figs. 3, 4). Future study of parental responses to nest predation could eliminate possible alternatives more effectively by inducing nests to fail experimentally and/or intensive study of a larger subset of pairs.

In our study, two components of parental investment with important consequences for fitness, egg mass and food loads brought to nestlings, did not vary with prior experience with nest predation. Egg mass increased slightly with Julian date, but, surprisingly, not inversely with clutch size. Food loads also varied seasonally but not inversely with feeding rates, as predicted or previously observed (i.e., Martin et al. 2000). In arid habitats such as sagebrush steppe, factors such as clutch size, egg mass, and food-load sizes may be largely driven by variation in parental quality and/or food availability (Martin 1987, Rotenberry and Wiens 1991, Zanette et al. 2006), neither of which we measured directly.

In conclusion, we document a lack of correlated variation in parental investment and care behaviors in response to
TABLE 4. Summary statistics for measures of parental care by Brewer's Sparrows in relation to previous experience within a season (nest type: pre-success first nests, post-success subsequent nests, pre-predation first nests, post-predation replacement nests), time of season (Julian date), and other covariates from ANCOVA models.

\begin{tabular}{|c|c|c|c|}
\hline Metric & df & $F$ & $P$ \\
\hline \multicolumn{4}{|l|}{ Clutch size } \\
\hline Nest type & 3,489 & 5.27 & 0.001 \\
\hline Julian date & 1,489 & 45.32 & $<0.001$ \\
\hline \multicolumn{4}{|l|}{ Egg mass } \\
\hline Nest type & 3,126 & 1.04 & 0.38 \\
\hline Julian date & 1,126 & 2.93 & 0.09 \\
\hline Clutch size & 1,126 & 0.11 & 0.74 \\
\hline \multicolumn{4}{|c|}{ Length of incubation on-bouts } \\
\hline Nest type & 3,83 & 6.61 & $<0.001$ \\
\hline Julian date & 1,83 & 0.61 & 0.44 \\
\hline \multicolumn{4}{|c|}{ Length of incubation off-bouts } \\
\hline Nest type & 3,83 & 2.20 & 0.09 \\
\hline Julian date & 1,83 & 0.18 & 0.67 \\
\hline \multicolumn{4}{|l|}{ Incubation visits $\mathrm{hr}^{-1}$} \\
\hline Nest type & 3,83 & 6.66 & $<0.001$ \\
\hline Julian date & 1,83 & 0.01 & 0.92 \\
\hline \multicolumn{4}{|l|}{ Nest attentiveness (\%) } \\
\hline Nest type & 3,83 & 1.81 & 0.15 \\
\hline Julian date & 1,83 & 1.66 & 0.20 \\
\hline \multicolumn{4}{|c|}{ Feedings of nestlings $\mathrm{hr}^{-1}$} \\
\hline Nest type & 3,98 & 6.39 & 0.001 \\
\hline Julian date & 1,98 & 2.93 & 0.09 \\
\hline Brood size & 1,98 & 0.95 & 0.33 \\
\hline Nestling age (day) & 1,98 & 0.19 & 0.66 \\
\hline
\end{tabular}

variation in ambient risk of nest predation by a multi-brooded songbird in a habitat with diverse nest predators. Instead, parents responded clearly to predation of their previous nest in that season. Environments that do not provide cues sufficient for prediction of the risk of predation may require that parents rely on direct experience with predation of their offspring as a form of prior information in order to gauge optimal investment in subsequent breeding attempts. Understanding the extent to which parents can adaptively respond to variable risk of predation of their offspring has implications for understanding spatial and temporal patterns of demography and the evolution of life-history strategies.

\section{ACKNOWLEDGMENTS}

We thank J. Bolser, B. Breen, K. Ellis, C. Forristal, C. Hill, K. Jewell, K. Nittinger, A. Saari, D. Rauch, D. Westerman, and especially C. Ricketts for assistance in the field. Funding for this work was provided by an National Science Foundation EPSCoR (Experimental Program to Stimulate Competitive Research) fellowship to ADC, the Breeding Biology Research and Monitoring Database (BBIRD), the Bureau of Land Management (Billings field office), a State Wildlife Grant from the Montana Department of Fish, Wildlife \& Parks, and the U.S. Forest Service's Rocky Mountain Research Station. We are grateful to J. Parks (Bureau of Land Management) for logistical and financial support and to S. Guenther and the Peters family for their 
support and logistical assistance. C. Martínez del Rio, J. J. Fontaine, and two anonymous reviewers provided very helpful comments on previous drafts of the manuscript. Specific equipment is identified simply to aid specific methods, not to represent an endorsement of these companies by the U.S. Geological Survey.

\section{LITERATURE CITED}

Burnham, K. P., And D. R. Anderson. 2002. Model selection and multimodel inference: a practical information-theoretic approach. Springer-Verlag, New York.

Chalfoun, A. D., And T. E. Martin. 2007a. Assessments of habitat preferences and quality depend on spatial scale and metrics of fitness. Journal of Applied Ecology 44:983-992.

Chalfoun, A. D., AND T. E. Martin. 2007b. Latitudinal variation in avian incubation attentiveness and a test of the food limitation hypothesis. Animal Behaviour 73:579-585.

Chalfoun, A. D., AND T. E. Martin. 2009. Habitat structure mediates predation risk for sedentary prey: experimental tests of alternative hypotheses. Journal of Animal Ecology 78:497-503.

CONWAY, C. J., AND T. E. MARTIN. 2000. Evolution of passerine incubation behavior: influence of food, temperature and nest predation. Evolution 54:670-685.

CRESSWELL, W. 1997. Nest predation: the relative effects of nest characteristics, clutch size and parental behavior. Animal Behaviour 53:93-103.

Deeming, D. C. 2002. Avian incubation: behaviour, environment, and evolution. Oxford University Press, New York.

Eggers, S., M. Griesser, And J. Ekman. 2005. Predator-induced plasticity in nest visitation rates in the Siberian Jay (Perisoreus infaustus). Behavioral Ecology 16:309-315.

Eggers, S., M. Griesser, M. Nystrand, and J. Ekman. 2006. Predation risk induces changes in nest-site selection and clutch size in the Siberian Jay. Proceedings of the Royal Society B 273: 701-706.

Eggers, S., M. Griesser, AND J. EkMAN. 2008. Predator-induced reductions in nest visitation rates are modified by forest cover and food availability. Behavioral Ecology 19:1056-1062.

Fontaine, J. J., And T. E. Martin. 2006. Parent birds assess nest predation risk and adjust their reproductive strategies. Ecology Letters 9:428-434.

Fontaine, J. J., M. Martel, H. M. Markland, A. M. Niklison, K. L. Decker, And T. E. Martin. 2007. Testing ecological and behavioral correlates of nest predation. Oikos 116:1887-1894.

GHALAMBOR, C. K., AND T. E. MARTIN. 2000. Parental investment strategies in two species of nuthatch vary with stage-specific predation risk and reproductive effort. Animal Behaviour 60:263-267.

Ghalambor, C. K., AND T. E. Martin. 2002. Comparative manipulation of predation risk in incubating birds reveals variability in the plasticity of responses. Behavioral Ecology 13:101-108.

GunNess, M. A., R. G. Clark, AND P. J. Weatherhead. 2001. Counterintuitive parental investment by female dabbling ducks in response to variable habitat quality. Ecology 82:1151-1158.

HAIG, D. 1990. Brood reduction and optimal parental investment when offspring differ in quality. American Naturalist 136:550-566.

KuDO, S. 2006. Within-clutch egg-size variation in a subsocial bug: the positional effect hypothesis. Canadian Journal of Zoology 84:1540-1544.

Lima, S. L. 2009. Predators and the breeding bird: behavioral and reproductive flexibility under the risk of predation. Biological Reviews 84:485-513.

Lima, S. L., AND L. M. DiLl. 1990. Behavioral decisions made under the risk of predation: a review and prospectus. Canadian Journal of Zoology 68:619-640.
LimA, S. L., AND P. A. Bednekoff. 1999. Temporal variation in danger drives antipredator behavior: the predation risk allocation hypothesis. American Naturalist 153:649-659.

Mahony, N. A., P. G. Krannitz, And K. Martin. 2006. Seasonal fecundity of sagebrush Brewer's Sparrow (Spizella breweri breweri) at the northern edge of its breeding range. Auk 123:512-523.

Manolis, J. C., D. E. Andersen, And F. J. Cuthbert. 2000. Uncertain nest fates in songbird studies and variation in Mayfield estimation. Auk 117:615-626.

MARTIN, T. E. 1987. Food as a limit of breeding birds: a life-history perspective. Annual Review of Ecology and Systematics 18:453487.

Martin, T. E. 1992. Interaction of nest predation and food limitation in reproductive strategies. Current Ornithology 9:163-197.

MARTIN, T. E. 1995. Avian life history evolution in relation to nest sites, nest predation and food. Ecological Monographs 65:101-127.

Martin, T. E. 2002. A new view of avian life-history evolution based on an incubation paradox. Proceedings of the Royal Society of London B 269:309-316.

Martin, T. E., And G. R. Geupel. 1993. Nest-monitoring plots: methods for locating nests and monitoring success. Journal of Field Ornithology 64:507-519.

Martin, T. E., AND J. V. BRISKIE. 2009. Predation on dependent offspring: a review of the consequences for mean expression and phenotypic plasticity in avian life history traits. Annals of the New York Academy of Sciences 1168:201-217.

Martin, T. E., P. R. Martin, C. R. Olson, B. J. Heidinger, and J. J. Fontaine. 2000. Parental care and clutch sizes in North and South American birds. Science 287:1482-1485.

Martin, T. E., R. D. Bassar, S. K. Bassar, J. J. Fontaine, P. Lloyd, H. A. Mathewson, A. M. Niklison, and A. Chalfoun. 2006. Life-history and ecological correlates of geographic variation in egg and clutch mass among passerine species. Evolution 60:390398.

Marzluff, J. M. 1988. Do Pinyon Jays alter nest placement based on prior experience? Animal Behavior 36:1-10.

Massaro, M., A. Starling-Windhof, J. V. Briskie, and T. E. MARTIN. 2008. Introduced mammalian predators induce behavioural changes in parental care in an endemic New Zealand bird. PloS One 3:1-7.

MAYFIELD, H. F. 1975. Suggestions for calculating nest success. Wilson Bulletin 87:456-466.

MuCHAI, M., AND DU Plessis, M. A. 2005. Nest predation of grassland bird species increases with parental activity at the nest. Journal of Avian Biology 36:110-116.

PÄRT, T., AND J. WRETENBERG. 2002. Do artificial nests reveal relative nest predation risk for real nests? Journal of Avian Biology 33: 39-46.

Peluc, S. I., T. S. Sillett, J. T. Rotenberry, and C. K. GhalamBOR. 2008. Adaptive phenotypic plasticity in an island songbird exposed to novel predation risk. Behavioral Ecology 19:830835.

Pietz, P. J., AND D. A. Granfors. 2000. Identifying predators and fates of grassland passerine nests using miniature video cameras. Journal of Wildlife Management 64:71-87.

REMEŠ, V. 2005. Nest concealment and parental behavior interact in affecting nest survival in the Blackcap (Sylvia atricapilla): an experimental evaluation of the parental compensation hypothesis. Behavioral Ecology and Sociobiology 58:326-333.

RofF, D. A. 1992. The evolution of life histories. Chapman \& Hall, New York.

Roper, J. J., And R. R. Goldstein. 1997. A test of the Skutch hypothesis: does activity at nests increase nest predation rates? Journal of Avian Biology 28:111-116. 
RotenBERRY, J. T., AND J. A. Wiens. 1989. Reproductive biology of shrubsteppe passerine birds: geographical and temporal variation in clutch size, brood size, and fledging success. Condor 91: $1-14$.

Rotenberry, J. T., AND J. A. Wiens. 1991. Weather and reproductive variation in shrubsteppe sparrows: a hierarchical analysis. Ecology 72:1325-1335.

RYTKÖNEN, S. 2002. Nest defence in Great Tits Parus major: support for parental investment theory. Behavioral Ecology and Sociobiology 52:379-384.

Sargeant, A. B., A. SovadA, And R. J. Greenwood. 1998. Interpreting evidence of depredation of duck nests in the prairie pothole region. U.S. Geological Survey, Northern Prairie Wildlife Research Center, Jameston, ND, and Ducks Unlimited, Inc., Memphis, TN.

Scheuerlein, T., J. Van’t Hof, And E. Gwinner. 2001. Predators as stressors? Physiological and reproductive consequences of predation risk in tropical Stonechats (Saxicola torquata axillaris). Proceedings of the Royal Society of London B 268:1575-1582.

SEALY, S. G. 1994. Observed acts of egg destruction, egg removal, and predation on nests of passerine birds at Delta Marsh, Manitoba. Canadian Field-Naturalist 108:41-51.

SHAFFER, T. L. 2004. A unified approach to analyzing nest success. Auk 121:526-540.

SKUTCH, A. F. 1949. Do tropical birds rear as many young as they can nourish? Ibis 91:430-455.
Slagsvold, T. 1982. Clutch size variation in passerine birds: the nest predation hypothesis. Oecologia 54:159-169.

Slagsvold, T. 1984. Clutch size variation of birds in relation to nest predation: on the cost of reproduction. Journal of Animal Ecology 53:945-953.

Stoks, R., M. De Block, H. van Gossum, and L. De Bruyn. 1999. Phenotypic shifts caused by predation: selection or life-history shifts? Evolutionary Ecology 13:115-129.

Thompson, F. R. III, AND D. E. Burhans. 2003. Predation of songbird nests differs by predator and between field and forest habitats. Journal of Wildlife Management 67:408-416.

Vander Haegen, W. M., M. A. Schroeder, and R. M. DeGraf. 2002. Predation on real and artificial nests in shrubsteppe landscapes fragmented by agriculture. Condor 104:496-506.

Wiens, J. A., J. T. Rotenberry, And B. Van Horne. 1986. A lesson in the limitations of field experiments: shrubsteppe birds and habitat alteration. Ecology 67:365-376.

WiLLIAMS, G. C. 1966. Natural selection, costs of reproduction and a refinement of Lack's principle. American Naturalist 100:687-690.

WingField, J. C. 2003. Control of behavioural strategies for capricious environments. Animal Behaviour 66:807-816.

Wisenden, B. D. 1993. Female convict cichlids adjust gonadal investment in current reproduction in response to relative risk of brood predation. Canadian Journal of Zoology 71:252-256.

ZANeTte, L., M. Clinchy, AND J. N. M. SMITH. 2006. Food and predators affect egg production in Song Sparrows. Ecology 87:2459-2467. 